\title{
Queen Execution and Caste Conflict in the Stingless Bee Melipona beecheii
}

\author{
Tom Wenseleers*, Adam G. Hart $\dagger$, Francis L. W. Ratnieks $\dagger \&$ Javier J. G. \\ Quezada-Euánł
}

*Laboratory of Entomology, Zoological Institute, University of Leuven, Leuven, Belgium; $\uparrow$ Laboratory of Apiculture \& Social Insects, Department of Animal and Plant Sciences, University of Sheffield, Sheffield, UK; $\ddagger$ Departamento de Apicultura, Facultad de Medicina Veterinaria, Universidad Autónoma de Yucatán, Mérida, Yucatán, México

\begin{abstract}
Caste conflict theory predicts that worker-destined individuals in insect colonies may try to develop as queens in order to gain greater direct reproduction. In situations where females can determine their own caste fate ('self-determination'), this is expected to lead to overproduction of queens. Theoretical predictions are supported by patterns of queen production in Melipona stingless bees. In Melipona, queens and workers are similar in size and develop in identical, mass-provisioned, sealed cells, a situation which permits self-determination. In line with predictions, many Melipona females, up to $16 \%$, selfishly develop as queens. Although these observations fit the predictions of caste conflict theory, some of the underlying assumptions remain incompletely tested. In particular, whether immature females can actually determine their own caste fate and whether queen production is really excessive rather than just an insurance against accidental queen loss? Here we test these assumptions. Queens and workers in colonies of Melipona beecheii in Yucatan, Mexico, had the same dry mass, showing that queen development is not conditional on above-average food provisioning. This supports the assumption that individuals can completely control their caste fate. Observations of 30 introduced virgin queens in three colonies showed that queens were killed rapidly and had a life expectancy of just $47 \mathrm{~h}$. A second method, using the number of virgin queens in natural colonies, also indicated a short life span, estimated at $27 \mathrm{~h}$. Rapid and efficient culling of virgin queens supports the hypothesis that queen production is excessive and results from caste fate conflict. In addition, we provide, for the first time, detailed behavioural descriptions of queen killing in this species.
\end{abstract}


Correspondence: Tom Wenseleers, Laboratory of Entomology, Zoological Institute, University of Leuven, Naamsestraat 59, B-3000 Leuven, Belgium. E-mail: tom.wenseleers@bio.kuleuven.ac.be

\section{Introduction}

Reproductive division of labour is the defining characteristic of eusociality (Wilson 1971; Oster \& Wilson 1978). In the advanced eusocial Hymenoptera (ants, some bees and wasps), morphologically distinct and irreversible female castes, queen and worker, occur during immature development (Wheeler 1986). An individual's caste greatly affects its reproductive potential. Queens, with adaptations for increased fecundity perform most of the reproduction, and workers, which have typically lost the ability to mate and found a colony, help to rear the queen's offspring into adulthood.

Theoretical analyses have shown that potential conflicts of interest over caste occur (Ratnieks 2001; Reuter \& Keller 2001; Strassmann et al. 2002; Wenseleers et al. 2003). Specifically, individual immature females can benefit by developing into queens rather than workers, thereby gaining greater direct reproduction (Ratnieks 2001; Reuter \& Keller 2001; Strassmann et al. 2002; Wenseleers et al. 2003). In many cases, immature females are unable to choose their own caste as their fate is determined by the quantity and quality of the food they receive from the adult workers ('nutritional caste determination'). One probable exception occurs in Melipona stingless bees. Here, immature female individuals can potentially control their own caste fate because queens and workers are similar in size and develop in identical, mass-provisioned cells which are sealed immediately after oviposition. In support of predictions from caste conflict theory, many females in Melipona, up to $16 \%$, selfishly develop as queens (Kerr 1950, 1969; Wenseleers \& Ratnieks 2004). This represents an excess, as Melipona is monogynous and reproduces by swarming, which requires the production of only few queens, just one for each swarm produced (Bourke \& Ratnieks 1999; Wenseleers et al. 2003; Wenseleers \& Ratnieks 2004). (Additional queens cannot found nests independently, as occurs in most eusocial Hymenoptera.)

Although queen overproduction in Melipona supports the predictions of caste conflict theory, some important assumptions underpinning the theory have not been properly verified. For example, it has often been suggested that Melipona females do not have total control over their caste fate and that only individuals in cells provisioned with more than average amounts of food can develop as queens (Darchen \& Delage-Darchen 1975, 1977; de Camargo et al. 1976; Engel 1979; Velthuis \& Sommeijer 1991; van Veen 2000). In support of nutritive caste determination, it appears that when female larvae are experimentally overfed, they more frequently develop as queens (M. beecheii: Darchen \& Delage-Darchen 1975, 1977; M. marginata, M. quadrifasciata, M. rufiventris, M. scutellaris: de Camargo et al. 1976; Engel 1979). van Veen (2000) also found that in M. beecheii the frequency of food discharges by workers in queen-producing cells was significantly less than that in worker-producing cells. Similarly, Kerr (1969) noted 
that in $M$. quadrifasciata queens are never produced when the number of food discharges in cells exceed 11. As the frequency of food discharge is negatively correlated with the amount of food put into a cell (Kerr et al. 1966), these observations suggest that females require more food if they are to successfully develop as queens.

Another potential criticism is that queen overproduction may occur for reasons other than caste conflict. For example, seemingly excessive queen production may be an insurance against accidental queen loss (Michener 1974; Engels \& Imperatriz-Fonseca 1990; Koedam et al. 1995) or a mechanism that allows workers to have a stock of queens from which to select the most fecund (Koedam et al. 1995).

Evidence that Melipona individuals cannot control their own caste fate or that queen production is not excessive but rather adaptive for the colony would undermine Melipona as a model for empirical tests of caste conflict theory. Here, we test whether food is a controlling factor in developing as a queen. We show that queens in $M$. beecheii females do not weigh more than workers suggesting, in contrast to previous studies (Darchen \& Delage-Darchen 1975, 1977; van Veen 2000), that individuals do not require more food to develop as queens (i.e. they do not develop in cells with larger than normal provisions) and that caste fate can be under complete individual control. We also test the assumption that queen production is excessive in Melipona by determining the life expectancy of newly eclosed virgin queens by two methods, and provide detailed observations of their fate. Most virgin queens are killed rapidly and aggressively by workers, and they have a mean life expectancy of just $27 \mathrm{~h}$. Were queens not killed rapidly, this would have indicated that they were being kept as 'spares' and we conclude that queen production is indeed excessive in this species.

\section{Materials and Methods}

\section{Study Organism}

All studies were conducted during Nov. 2001 using wild-collected Melipona beecheii colonies that had been re-housed in wooden hive boxes and were being maintained at the Department of Apiculture, Autonomous University of Yucatan, Merida, Mexico.

\section{Weights of Queens and Workers}

It was suggested by van Veen (2000) that queens and workers of M. beecheii require different amounts of food to complete their development and, therefore, that caste fate is not under individual control. If this were the case, then newly emerged queens should be heavier than workers (assuming that queens and workers have similar metabolic rates). To test this, we collected a total of six combs from three $M$. beecheii colonies (two from each of colonies 4, 5 and 6) and allowed individuals to eclose in an incubator $\left(29^{\circ} \mathrm{C}\right)$. Queens and workers can be 
readily distinguished because queens have a smaller head and thorax, a slightly larger abdomen and lack corbiculae (pollen baskets). Queens and workers were collected as they emerged from the comb and their fresh and dry (desiccated for $5 \mathrm{~d}$ at $80^{\circ} \mathrm{C}$ ) weights determined (all individuals were $<12$-h old when measured). This procedure also provided data on the proportion of females that developed as queens (see the section 'The Life Expectancy of Virgin Queens in Natural Colonies'). Fresh and dry weights of queens and workers were compared using a general linear model (GLM) accounting for potential intercolony differences in individuals' weights (Neter et al. 1996).

\section{Observations of Queen Killing}

To determine the fate of newly eclosed virgin queens, we set up three observation colonies containing the mother queen, a small piece of comb and approx. 100 workers housed in a glass-lidded box of $14.2 \mathrm{~cm} \times 8.5 \mathrm{~cm} \times 3.5 \mathrm{~cm}$ dimension. This colony size is small (natural colony sizes $\mathrm{n}=500-1500$ workers) and was chosen to allow us to observe all bees simultaneously. Colonies were not allowed to forage naturally but were provided with pollen and honey pots inside the nest from which they could feed ad libitum. We introduced approx. 10 newly eclosed marked queens and approx. 10 newly eclosed marked workers into these colonies through a small hole in the side of the nest box (queens: colony 1 and 2: $\mathrm{n}=10$; colony $3: \mathrm{n}=9$; workers: colony 1 and $2: \mathrm{n}=10$; colony $3: \mathrm{n}=11$ ). Introduced queens and workers had eclosed in an incubator from a comb originating from the same test colony that they were to be introduced into. The bees were weighed and fed with honey before introduction.

Colonies were observed for 10 min every hour for a total of $60 \mathrm{~h}$, and any aggressive acts towards or among the queens were noted. If aggression towards or between the introduced workers occurred, then it was also noted. Dead individuals were collected and examined for injuries. The survival of the introduced queens and workers was compared using a Gehan's Wilcoxon test, as implemented in Statsoft Statistica 6.0 (Statsoft 1995), which takes into account the censored nature of the data, i.e. the fact that it was unknown for how much longer the queens alive at the end of the experiment $(60 \mathrm{~h})$ would have survived if observations would have continued. Proportional hazard (Cox) regression was used to test whether the weight of the introduced queens affected their chances of survival (Statsoft 1995).

\section{The Life Expectancy of Virgin Queens in Natural Colonies}

The estimates of the life expectancy of virgin queens determined in the section 'Observations of Queen Killing' may be biased as a result of the artificial experimental procedure we used, including the fact that colonies were smaller than typical which would likely lower the rate at which excess queens were killed. Therefore, we also indirectly determined the life expectancy of the queen in unmanipulated colonies. We did this by comparing the proportion of queens 
eclosing from combs with the proportion of those present in the colony. At any given time, one should find a proportion of queens in the colony of

$\mathrm{c}=\frac{\mathrm{q} \cdot \mathrm{b}}{\mathrm{w} \cdot(1-\mathrm{b})+\mathrm{q} \cdot \mathrm{b}}$

where ' $q$ ' and ' $w$ ' are the life expectancies of queens and workers, respectively, and ' $b$ ' is the proportion of females that are queens in the brood combs. Solving this equation for 'q', one can estimate the average queens' life expectancy as:

$\mathrm{q}=\mathrm{w} \cdot \frac{\mathrm{c}}{1-\mathrm{c}} \cdot \frac{1-\mathrm{b}}{\mathrm{b}}$

As a constant mortality rate of ' $m$ ' leads to a life expectancy of

$\int_{0}^{\infty}(1-\mathrm{m})^{\mathrm{i}} \mathrm{di}=\frac{-1}{\ln (1-\mathrm{m})}$

the above queen life expectancy 'q' implies a mortality rate of

$\mathrm{m}=1-\mathrm{e}^{-1 / \mathrm{q}}$

The proportion of queens present in the colony ('c') was measured by anaesthetizing three complete colonies with carbon dioxide and carefully counting all workers, queens and, if present, males. The proportion of females that were developing as queens ('b') was measured from the three colonies as described above by uncapping cells. To obtain a more reliable estimate, our data were combined with those of Darchen \& Delage-Darchen (1975), who had measured the same parameters from a further three colonies of $M$. beecheii, also in Nov. (1974) in the Yucatan. The life expectancy of workers has been estimated at $51 \mathrm{~d}$ $(\mathrm{SD}=15 \mathrm{~d})$ for $M$. beecheii in Costa Rica (Biesmeijer \& Toth 1998), and a similar estimate of $49 \mathrm{~d}$ has been obtained for M. beecheii in Merida (L. Medina Medina, pers. comm.). In our calculations, we use the published figure of $51 \mathrm{~d}$ (Biesmeijer \& Toth 1998).

The lower and upper $95 \%$ confidence limits on the mean queen life expectancy were calculated as the 2.5th and 97.5th percentiles of a simulated distribution of the average colony estimates (Table 1), using simulated binomial proportions for parameters 'b' and 'c' and a normally distributed estimate for ' $w$ ' $(\overline{\mathrm{x}}=51 \mathrm{~d}$, SD $15 \mathrm{~d}$; Biesmeijer \& Toth 1998; number of iterations: 100 000).

\section{Results}

\section{Weight of Queens and Workers}

The fresh weight of newly eclosed queens $(\overline{\mathrm{x}}=48.2 \mathrm{mg}, \mathrm{n}=155)$ was significantly less than that of newly eclosed workers $(\overline{\mathrm{x}}=57.1 \mathrm{mg}, \mathrm{n}=368$; 
Table 1: Proportions of females who were pupal queens present in the brood combs or adult queens free in the colony, and the inferred life expectancy of virgin queens [equation (2)]

\begin{tabular}{|c|c|c|c|c|c|c|}
\hline \multirow[b]{2}{*}{ Colony } & \multicolumn{2}{|c|}{$\begin{array}{l}\text { Queens in } \\
\text { brood combs }\end{array}$} & \multicolumn{2}{|c|}{$\begin{array}{l}\text { Queens in the } \\
\text { colony }\end{array}$} & \multirow{2}{*}{$\begin{array}{l}\text { Life expectancy } \\
\text { of virgin queens } \\
\text { (hours) }\end{array}$} & \multirow[b]{2}{*}{ Reference } \\
\hline & $\%$ & $\mathrm{n}$ & $\%$ & $\mathrm{n}$ & & \\
\hline 1 & 18 & 521 & 0.65 & 1226 & 36.5 & 1 \\
\hline 2 & 14 & 615 & 0.35 & 1131 & 26.0 & 1 \\
\hline 3 & 22 & 51 & 0.22 & 1843 & 9.7 & 1 \\
\hline 4 & 22 & 560 & 1.50 & 532 & 65.7 & 2 \\
\hline 5 & 23 & 732 & 0.49 & 612 & 20.1 & 2 \\
\hline 6 & 17 & 1184 & 0.00 & 1273 & 0.0 & 2 \\
\hline Average & 20 & & 0.54 & & 26.7 & \\
\hline $95 \% \mathrm{CI}$ & $17-22$ & & $0.34-0.77$ & & $14.8-43.2$ & \\
\hline
\end{tabular}

${ }^{1}$ This study. ${ }^{2}$ Darchen \& Delage-Darchen (1975).

GLM: $\quad F_{1}=4304.4, p<10^{-13}$ ). Their dry weights, however, were not significantly different (queens: $\overline{\mathrm{x}}=11.4 \mathrm{mg}, \mathrm{n}=117$; workers: $\overline{\mathrm{x}}=11.6 \mathrm{mg}$, $\mathrm{n}=337$; GLM: $\mathrm{F}_{1}=1.06, \mathrm{p}=0.4$; Fig. 1). The lower fresh weight of queens may be caused by differential water loss during development (queens develop 12 d faster than workers; Velthuis \& Sommeijer 1991).

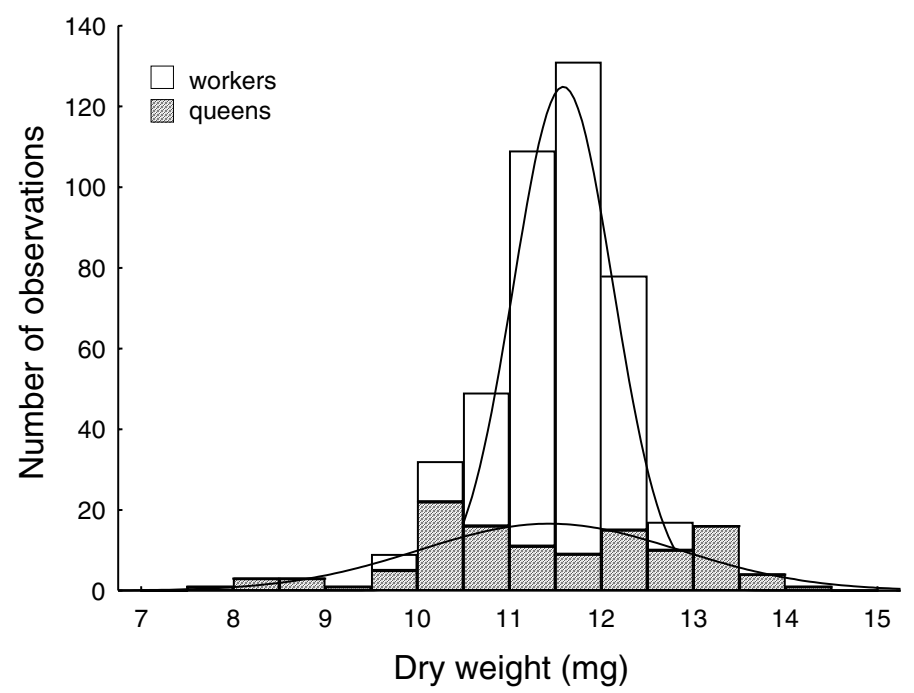

Fig. 1: Distribution of the dry weights of newly emerged queens and workers in Melipona beecheii (pooled data from three colonies) 


\section{Observations of Queen Killing}

When newly eclosed virgin queens and workers were introduced into the observation colonies, queens were quickly killed by the resident workers (only half survived until $28 \mathrm{~h}$ after introduction, total $\mathrm{n}=29$, and only nine were alive after $60 \mathrm{~h}$ ), whereas all but one of the workers (total $\mathrm{n}=31$ ) survived until the end of the experimental period (60 h) (Fig. 2). The dead worker showed no signs of injury, in contrast with dead queens (see below). The difference in survival between queens and workers was highly significant (Gehan's Wilcoxon test, p $<0.000001$; Fig. 2). The survival curve of queens (Fig. 2) was not significantly different from an exponential decline, implying that the mortality rate of the queens was constant over the course of the experiment $\left(\chi_{10}^{2}=6.37, \mathrm{p}>0.05\right)$.

Two mechanisms of queen killing were seen. In the first, a single worker grabbed a queen, placed its mandibles between the queen's head and thorax, and decapitated it. This took only $4-12 \mathrm{~s}(\overline{\mathrm{x}}=8 \mathrm{~s}, \mathrm{SD}=3 \mathrm{~s}, \mathrm{n}=4$ observed cases), and never involved multiple workers (Fig. 3a). In the second, as many as five workers grabbed the queen's extremities (legs, mouthparts, antennae or tip of the abdomen), and dragged it around inside the colony, sometimes forcefully biting off one or more legs or antennae (Fig. 3b). Such aggressive acts could last for more than $1 \mathrm{~h}(\tilde{\mathrm{x}}=90 \mathrm{~s}$, range $30 \mathrm{~s}$ to $1 \mathrm{~h}, 13$ observed cases $)$, and usually involved multiple workers ( $\tilde{\mathrm{x}}=3$ workers, range $1-5$ workers, $\mathrm{n}=13)$. No

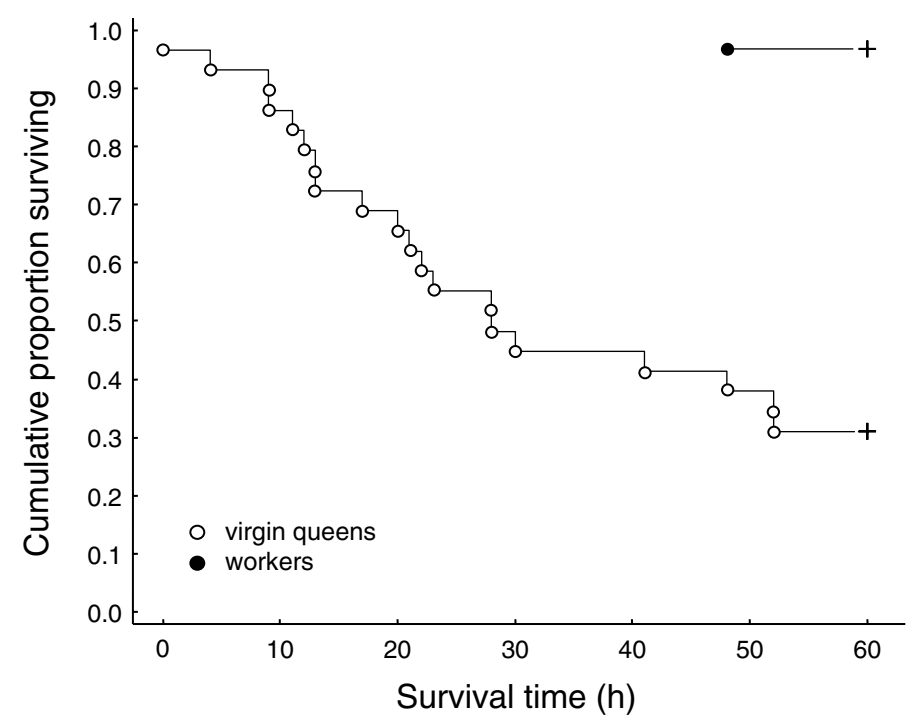

Fig. 2: Survival of newly eclosed virgin queens and workers of Melipona beecheii introduced into their own colonies (Kaplan-Meier analysis). Half of all virgin queens $(n=29)$ were killed within $28 \mathrm{~h}$ after introduction, whereas all but one of the workers $(\mathrm{n}=31)$ survived for the full duration of the experiment, $60 \mathrm{~h}$. This difference in survival is very highly significant (Gehan's Wilcoxon test, $\mathrm{p}<0.000001)$. Data are pooled across three trials performed using three different colonies. Open circles and crosses are complete and censored observations, respectively 
a

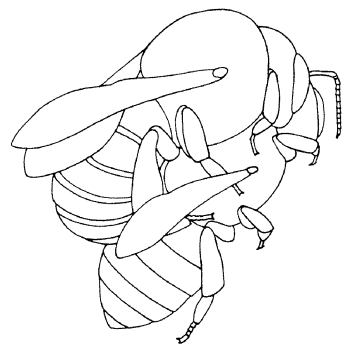

b

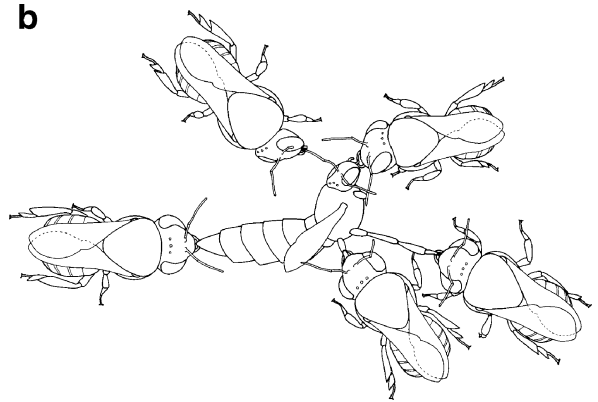

Fig. 3: Drawings from photographs of queen executions in M. beecheii. (a) A quarter of all queens killed were decapitated. Decapitation proceeds rapidly and is achieved by a single worker assuming a position on the back of the virgin queen and removing the queen's head with her mandibles. (b) Queens

not decaptitated are mostly killed by small groups of workers pulling on the queen's extremities

aggressive interactions among the virgin queens were seen. At the end of the experiment, after 60 h, 20 of $29(69 \%)$ of the introduced queens had died $(9 / 9,6 /$ 10 and $5 / 10$ in colonies 1, 2 and 3, respectively). Five of these (17\% of total queens, $25 \%$ of killed queens) were decapitated, 10 (34\% total, 50\% killed) had antennae or legs missing, one (3\% total, $5 \%$ killed) had bite marks on the head and abdomen and a further one (3\% total, $5 \%$ killed) had its abdomen nearly bitten off. The remaining three (10\% total, $15 \%$ killed) showed no obvious signs of injury; they may either have died an accidental death or have died as a result of starvation (trophallaxis with nestmates or feeding from pollen and honey pots were not observed). The estimated mean life expectancy of queens was $47 \mathrm{~h}$. Although there was significant variation in the weight of the introduced queens, $36.3-60.5 \mathrm{mg}(\overline{\mathrm{x}}=50.3 \mathrm{mg}, \mathrm{SD}=6.7 \mathrm{mg})$, heavier queens did not survive longer (Cox regression, $\mathrm{p}=0.47$ ).

Queens frequently tried to avoid being killed by fleeing from workers, hiding underneath the comb or honey pots, or by feigning death. In one striking case, in colony 1, a queen feigned death, remaining immobile for $14 \mathrm{~h}$, in this way successfully outliving all other virgin queens. It then started behaving very aggressively, even towards the mother queen. Eventually, however, the queen was killed by the workers $48 \mathrm{~h}$ after its introduction.

\section{Life Expectancy of Virgin Queens in Natural Colonies}

Many females in the brood combs, 14-23\% (Table 1), were developing into queens but few, $0-1.5 \%$ of the adult females (workers + queens), in the colony were queens. This indicates that in natural colonies queens are killed very quickly after emergence: equation (2) gives an estimate for mean queen life expectancy of just $27 \mathrm{~h}$ (95\% confidence limits: 15-43 h; Table 1). There is also a borderline significant trend for the life expectancy of the queen to be lower in larger colonies (Spearman's rank $\mathrm{R}=-0.71, \mathrm{p}=0.1$ ). This is as expected if queens are killed as a result of the mass action of, or the interaction with, many workers. 


\section{Discussion}

Our results verify the two assumptions that we tested: (1) in $M$. beecheii, queens do not weigh more than the workers (the fresh weight was less, the dry weight the same), implying that queens do not develop in cells that receive more food, hence supporting self-determination, and (2) queens are quickly killed by workers, implying that queens are not kept as spares (Michener 1974; Engels \& Imperatriz-Fonseca 1990; Koedam et al. 1995).

It was suggested by van Veen (2000) that $M$. beecheii queens develop in cells containing more food, and therefore that caste is not self-determined, but this relies on observations from different species. Queen-producing cells received fewer food discharges than worker-producing cells in a study of $M$. beecheii (van Veen 2000) and the amount of food put into a cell was inversely proportional to the number of workers discharging food into it in a study of $M$. quadrifasciata (Kerr et al. 1966). We are not aware of any data relating the number and quantity of food discharges in $M$. beecheii but our finding that queens do not weigh more than workers strongly suggests self-determination rather than 'nutritional caste determination'.

Almost a complete overlap of the distributions of the weights of queens and workers has also been shown in M. quadrifasciata, although in this species queens were slightly heavier, on average, than workers (Kerr 1969). Nevertheless, the difference was small, and could easily be explained by factors other than nutritional caste determination. For example, it could be that when the colony as a whole receives more nutrition, females more frequently become queens in response to the chances for swarming being better (Wenseleers et al. 2003). This interpretation is supported by Moo-Valle et al. (2001), who showed that in $M$. beecheii, increased colony-wide nutrition increases queen production. It is also supported by Kerr (1969), who showed that during periods of high queen production in $M$. quadrifasciata, not only queens, but also the workers are heavier. The experiments showing that overfeeding of female larvae resulted in increased queen production can be explained in the same way (Darchen \& Delage-Darchen 1975, 1977; de Camargo et al. 1976; Engel 1979). It could also be a phylogenetically preserved response to nutritional caste determination which occurs in all the nonMeliponine genera (Engels \& Imperatriz-Fonseca 1990), and is likely to be ancestral in stingless bees (Costa et al. 2003). Hence, the assumption that an individual has complete control over its caste fate in $M$. beecheii is strongly supported and is also consistent with other studies which appear, on the surface, to suggest otherwise.

With regard to aggression against newly eclosed virgin queens, a previous study suggested that 'during the first few days the workers mostly take no notice of them' (Engels \& Imperatriz-Fonseca 1990). In this study, newly eclosed virgin queens were killed rapidly by the workers, with experimentally introduced queens having a half-life of only $28 \mathrm{~h}$ and a mean life expectancy of $47 \mathrm{~h}$. Rapid execution of queens has also been recorded in M. favosa (Koedam et al. 1995). 
Our experimental manipulations were not the cause of the short life expectancy of the queens, as the control workers, which were introduced using the same procedures, suffered virtually no mortality. In addition, our estimate of life expectancy based on the number of surviving queens in natural colonies gave an even lower value of $27 \mathrm{~h}$. Newly eclosed queens were, for the most part, killed quickly by the workers. A quarter were decapitated by single workers in a process taking only $8 \mathrm{~s}$, and most of the other dead queens were killed by small groups of workers. Importantly, queens were not passive victims in this cull. They frequently were observed fleeing and hiding from workers and even feigning death (also observed by van Veen et al. 1999).

It has been suggested that seemingly excessive queen production may be an insurance mechanism to provide spare queens in case of queen failure (Michener 1974; Engels \& Imperatriz-Fonseca 1990; Koedam et al. 1995) or to provide a stock of queens from which the most fecund can be selected before swarming (Koedam et al. 1995). We do not think that these are parsimonious hypotheses to explain the level of queen production in Melipona. First, it is unlikely that a colony would need as many as $16 \%$ of its females to be 'insurance' against the loss of the mother queen. Secondly, the wholesale, rapid and efficient slaughter of newly eclosed queens suggests that the queens are neither spare nor being assessed for quality. In one colony (colony 6) there were no virgin queens, which is not consistent with the insurance hypothesis. Thirdly, in species where insurance queens are kept, they are often maintained in special chambers or 'queen prisons', which is not the case in Melipona (Engels \& Imperatriz-Fonseca 1990). In addition to the short life expectancy of virgin queens there was a borderline significant trend towards reduced life expectancy in larger colonies. Larger colonies are precisely the colonies most likely to swarm and should be least likely to kill virgin queens if the hypothesis were correct. Similarly, if queens were being kept in a pool from which the most fecund one would be drawn, then we would expect the larger queens to survive longer, which is not what we found.

Our study supports the assumptions of excessive queen production and selfdetermination of caste and thereby gives support to the caste conflict theory, in general, and to the use of Melipona as model for caste conflict studies. Another situation where caste conflict is likely important is in the production of undersized dwarf queens from worker cells, which occurs in some stingless bees and ants (Engels \& Imperatriz-Fonseca 1990; Bourke \& Ratnieks 1999; Wenseleers et al. 2003). This seems to be a good case of selfish self-determination of caste, with individuals in worker cells avoiding their non-reproductive worker fate as best they can. However, data on the weights of undersized queens and workers are needed to support the hypothesis that small queens are females that selfishly choose to become queens even when fed with an amount of food normally only sufficient for worker development. If, as in Melipona, self-determination and excess queen production were demonstrated, it would add greatly to the generality of caste conflict in social insects. 


\section{Acknowledgements}

This work was supported by the 'INSECTS' EUTMR network, by a Marie-Curie post-doctoral fellowship to T. W. and by a NERC grant to A. G. H. The authors thank Seirian Sumner for her help and encouragement in the field and Luis Medina-Medina and the rest of the Department of Apiculture, Merida, for their hospitality. We thank Leila Morris for Fig. 3.

\section{Literature Cited}

Biesmeijer, J. C. \& Toth, E. 1998: Individual foraging, activity level and longevity in the stingless bee Melipona beecheii in Costa Rica (Hymenoptera, Apidae, Meliponinae). Insectes Soc. 45, $427-443$.

Bourke, A. F. G. \& Ratnieks, F. L. W. 1999: Kin conflict over caste determination in social Hymenoptera. Behav. Ecol. Sociobiol. 46, 287-297.

de Camargo, C. A., de Almeida, M. G., Parra, M. G. N. \& Kerr, W. E. 1976: Genetics of sex determination in bees. IX. Frequencies of queens and workers from larvae under controlled conditions (Hymenoptera: Apoidea). J. Kansas Entomol. Soc. 49, 120-125.

Costa, M. A., Del Lama, M. A., Melo, G. A. R. \& Sheppard, W. S. 2003: Molecular phylogeny of the stingless bees (Apidae, Apinae, Meliponini) inferred from mitochondrial 16S rDNA sequences. Apidologie 34, 73-84.

Darchen, R. \& Delage-Darchen, B. 1975: Contribution à l'étude d'une abeille du Mexique Melipona beecheii B. (Hymenoptère: Apide). Apidologie 6, 295-339.

Darchen, R. \& Delage-Darchen, B. 1977: Sur le déterminisme des castes chez les Mélipones (Hyménoptères Apidés). Bull. Biol. Fr. Belg. 111, 91-109.

Engel, M. S. 1979: Is caste determination in Melipona quadrifasciata, a stingless bee, influenced by 9oxo-decenoic acid? Insectes Sociaux 26, 273-278.

Engels, W. \& Imperatriz-Fonseca, V. L. 1990: Caste development, reproductive strategies, and control of fertility in honey bees and stingless bees. In: Social Insects. An Evolutionary Approach to Castes and Reproduction (Engels, W., ed.). Springer-Verlag, Berlin, Heidelberg, pp. 167-230.

Kerr, W. E. 1950: Genetic determination of castes in the genus Melipona. Genetics 35, 143-152.

Kerr, W. E. 1969: Some aspects of the evolution of social bees (Apidae). In: Evolutionary Biology, Vol. 3. (T. Dobzhansky, M. K. Hecht, W. C. Steere, eds.) Appleton-Century Crofts, New York, pp. $119-175$.

Kerr, W. E., Stort, A. C. \& Montenegro, M. J. 1966: Importância de alguns fatôres ambientais na determinação das castas do gênero Melipona. An. Acad. Bras. Ciênc. 38, 149-168.

Koedam, D., Aguilar-Monge, I. \& Sommeijer, M. J. 1995: Social interactions of gynes and their longevity in queenright colonies of Melipona favosa (Apidae: Meliponinae). Neth. J Zool. 45, $480-494$.

Michener, C. D. 1974: The Social Behavior of the Bees. Harvard Univ. Press, Cambridge, MA.

Moo-Valle, H., Quezada-Euan, J. J. G. \& Wenseleers, T. 2001: The effect of food reserves on the production of sexual offspring in the stingless bee Melipona beecheii (Apidae, Meliponini). Insectes Soc. 48, 398-403.

Neter, J., Wasserman, W. \& Kutner, M. H. 1996: Applied Linear Statistical Models. McGraw-Hill, New York.

Oster, G. F. \& Wilson, E. O. 1978: Caste and Ecology in the Social Insects. Princeton Univ. Press, Princeton, NJ.

Ratnieks, F. L. W. 2001: Heirs and spares: caste conflict and excess queen production in Melipona bees. Behav. Ecol. Sociobiol. 50, 467-473.

Reuter, M. \& Keller, L. 2001: Sex ratio conflict and worker production in eusocial Hymenoptera. Am. Nat. 158, $166-177$.

Statsoft, I. 1995: STATISTICA for Windows (Computer Program Manual). StatSoft, Inc., Tulsa, OK, http://www.statsoft.com. Site accessed and validated on 26/07/04.

Strassmann, J. E., Sullender, B. W. \& Queller, D. C. 2002: Caste totipotency and conflict in a largecolony social insect. Proc. R. Soc. Lond. Ser. B - Biol. Sci. 269, 263-270.

van Veen, J. W. 2000: Cell provisioning and oviposition in Melipona beecheii (Apidae, Meliponinae), with a note on caste determination. Apidologie 31, 411-419. 
van Veen, J. W., Sommeijer, M. J. \& Aguilar Monge, I. 1999: Behavioural development and abdomen inflation of gynes and newly mated queens of Melipona beecheii (Apidae, Meliponinae). Insectes Soc. 46, 361-365.

Velthuis, H. H. W. \& Sommeijer, M. J. 1991: Roles of morphogenetic hormones in caste polymorphism in stingless bees. In: Morphogenetic Hormones of Arthropods (Gupta, A. P., ed.). Rutgers Univ. Press, New Brunswick, NJ, pp. 346-383.

Wenseleers, T. \& Ratnieks, F. L. W. 2004: Tragedy of the commons in Melipona bees. Proc. R. Soc. Lond. Series B - Biol. Sci. (Suppl.), 271, 5310-5312.

Wenseleers, T., Ratnieks, F. L. W. \& Billen, J. 2003: Caste fate conflict in swarm-founding social Hymenoptera: an inclusive fitness analysis. J. Evol. Biol. 16, 647-658.

Wheeler, D. E. 1986: Developmental and physiological determinants of caste in social hymenoptera: evolutionary implications. Am. Nat. 128, 13-34.

Wilson, E. O. 1971: The Insect Societies. Harvard Univ. Press, Cambridge, MA.

Received: April 28, 2004

Initial acceptance: June 11, 2004

Final acceptance: June 18, 2004 (L. Sundström) 